International Journal of Life Sciences
Available online at www.sciencescholar.us
Vol. 6 No. 1, April 2022, pages: $1-9$
e-ISSN: 2550-6986, p-ISSN: $2550-6994$
https://doi.org/10.53730/ijls.v6n1.3148

\title{
The Circular Economy and Environmental Training as Care of the Common House
}

\begin{abstract}
Crossiark
Gabriela Andreina Rebanales García a, Yeneri Carolina Rivas b

Manuscript submitted: 27 Oct 2021, Manuscript revised: 18 Nov 2021, Accepted for publication: 09 Dec 2021

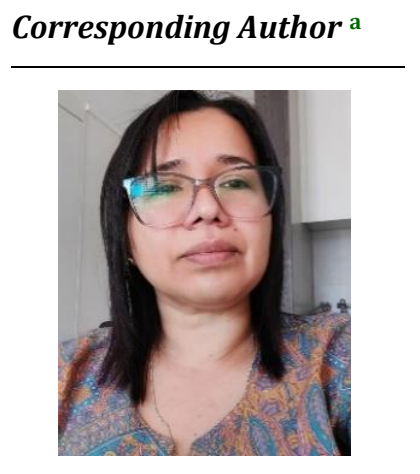

Keywords

circular economy;

common house;

environment;

environmental training;

Abstract

The economy circular is a business model that is based on the 3Rs (reduce, reuse, recycle) of natural resources, the industrial revolution has made companies create many products, which promote consumerism without awareness of the damage it generates to the "common house" due to environmental pollution. We have worked based on a descriptive-documentary methodology, applying the analysis and interpretation of content, it was limited to the review of articles published in digital magazines, located in databases such as Redalyc, Scopus, WOS, Latindex 2.0, among the results The challenge is for countries to implement strategies that achieve sustainable development, with a focus on the circular economy and care for the "common home". Invest in technology, where the 3R methodology (reduce, reuse, recycle) could do that significantly improve the processes of the productive sectors. Implement laws in all countries that regulate the methods of production and treatment of waste from industries and provide incentives to those companies that promote sustainability in order to achieve sustainable development.
\end{abstract}

sustainable development;

International Journal of Life Sciences (C) 2022.

This is an open access article under the CC BY-NC-ND license (https://creativecommons.org/licenses/by-nc-nd/4.0/).

\section{Contents}

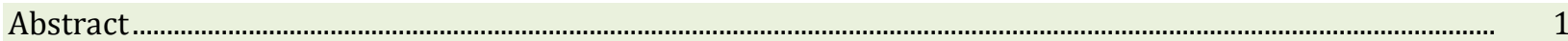

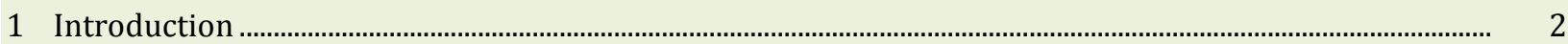

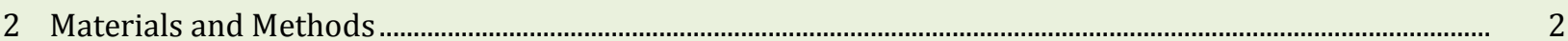

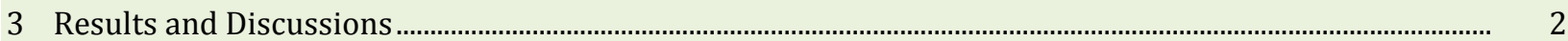

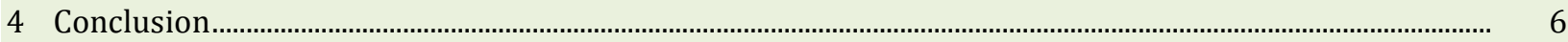

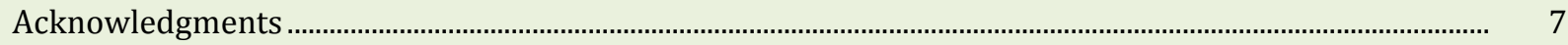

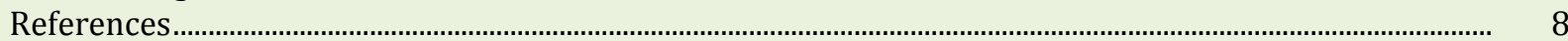

a Colegio Alberto Pérez institución Teresiana Maipú, Santiago de Chile, Chile

b Pontificia Universidad Católica del Ecuador, Portoviejo, Manabí, Ecuador 


\section{Introduction}

Currently the circular economy is being implemented in different parts of the world, in many different areas and places, of course the path ahead is long, different organizations, institutions have generated significant contributions, one of these institutions has been the Catholic Church in its highest representative Pope Francis in his encyclical "Laudato si" that seeks to guide our actions, discern a response to the ecological crisis with deep responsibility, believers and non-believers are invited to a spiritual and cultural revolution to achieve an ecology integral. During the last ten years, the consumption of raw materials has been very high, which will significantly compromise the planet if it is not possible to stop or change the current linear model of production and consumption. This concern has been promoted by environmentalists such as Rachel Carson, since the 1960s and since the 1980s by various governments (Prieto-Sandoval et al., 2018; Neitz \& Neitz, 2001).

In this sense, the circular economy is presented as a viable alternative to improve the linear model and respond to the challenges of economic and productive growth since it promotes the cyclical flow for the extraction, transformation, distribution, use and recovery of materials, energy of the products available in the market. This article presents important aspects of the circular economy, trying to give an overview. In the first place, the concept of circular economy is defined, the principles on which it is based are presented, the most relevant characteristics are indicated, a brief analysis is made of the six chapters of the encyclical "Laudato Si". After the introduction, the part 2 explains the methodology used in the research, in part 3 "analysis of the results" the theoretical framework of the circular economy is presented; finally, section 4 presents the conclusions. The objective of the research is to demonstrate that the circular economy as a production model and environmental training is the viable option for the care of the common home. The methodology used is based on a descriptive-documentary methodology, applying content analysis as a technique for information processing (Booth et al., 2005; Moraga et al., 2019).

\section{Materials and Methods}

The research design, which has been used is descriptive, the keywords were established for the search of information in different databases, both national and international to demonstrate that the circular economy and training Environmental factors are essential in the $21^{\text {st }}$ century and a viable option in the care of the common home. The inductive-deductive method was used in the discourse, another of the methodologies used to carry out the research was the bibliographic review in different sources of information (Jabbour, 2013; Perron et al., 2006).

\section{Results and Discussions}

The current production system is based mainly on a linear process of resource consumption (extractmanufacture-consume-eliminate) the goods are produced from raw materials, then sold, used and by Last discarded by waste which has caused not only the depletion of natural resources, but also the generation of tons of garbage. Currently, according to Martínez \& Porcelli (2018), 82 million tons of garbage are produced, the problem is likely to worsen as the global middle class will multiply, and millions of people will join consumption habits. Since 1989, the book by Pearce and Turner has already spoken of the circular economy and over the years it has been acquiring more and more importance, in the different political, social, business and economic spheres and of course in the field academic that has had greater strength and the journey it has is immense.

The environmental and social problem has derived what is known as sustainable development, which proposes that social and environmental systems have the same importance as economic systems, causing a paradigm shift that understands and analyzes the ways in which economies produce and consume goods and 
services. In this sense, the Chilean legislature assumes and puts into practice international standards on the matter, generating legislative instruments to control emissions, waste, and the damage that the culture of consumerism produces, extract, produce, buy and dispose of. The Chilean REP Country Law, apart from formalizing the recycling industry, invites the development of product use practices. Suazo Páez (2017), first and great step for the care of Creation. The world, the "common home" is overloaded in the use of natural resources, it must move towards a restorative and regenerative model that builds economic, social, and environmental capital, it is important to change the equation greater economic growth, greater use of resources finite, it is time to move towards a circular economy, adding value and extending the useful life of the materials in use (FCH Fundación Chile, 2021).

\section{Transition process}

In Figure 1, the transition processes can be seen. From a linear economy to a circular economy.

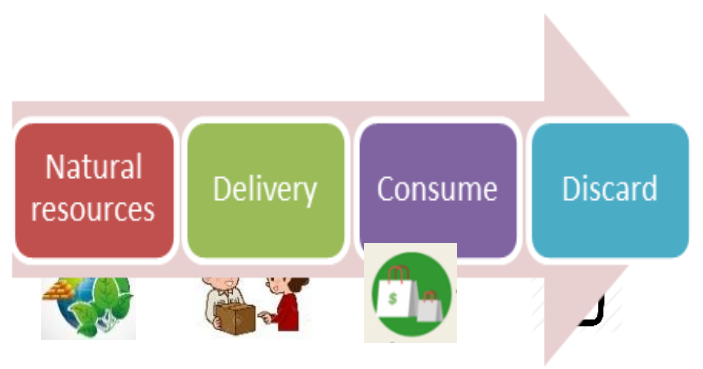

From a linear economy

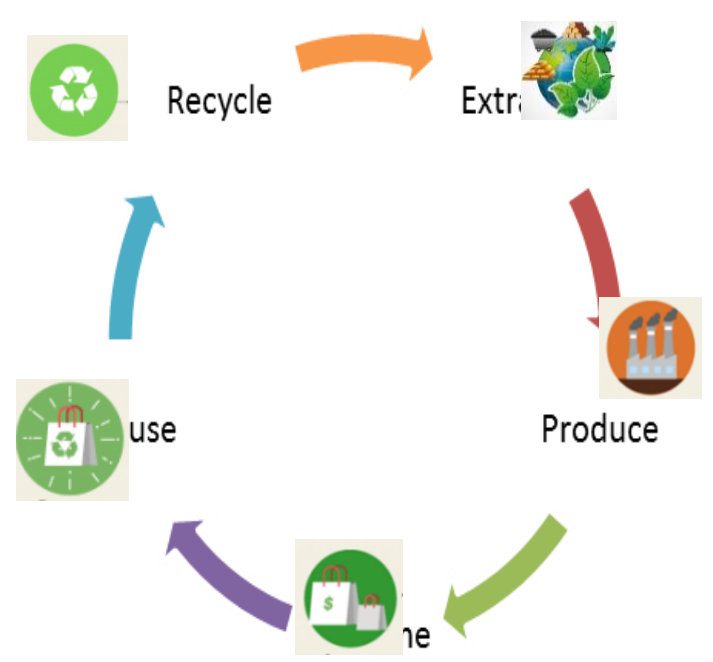

....to a circular economy

Figure 1. Transition process: from a linear economy to a circular economy

\section{Circular economy}

The concept of circular economy is essential to understand and propose ways to face the problems in an economically viable way and establish dynamic social and technical strategies that lead to responsible production and consumption. The circular economy was born as an alternative to the linear production system. It is mainly a cycle that preserves and optimizes in each process and each stage the use of the resources that are used (Suazo Páez, 2017). According to Cerdá \& Khalilova (2016), the circular economy proposes to keep products, components and materials at their highest levels of use. The concept differentiates between biological cycles and technical cycles, it is a positive continuous development cycle that maintains and increases natural capital, optimizes the risks of the system, the circular economy proposes paradigm changes, of mental schemes that seek to "reduce, reuse and recycle". For a transformation that lasts over time, which allows reducing the impact caused by the activities of humanity on the environment or Creation seen from a religious point of view. In this sense Lett (2014), points out the following.

"The circular economy model implies a new modality that gives waste a dominant role and is based on the intelligent reuse of waste, whether of an organic nature or of technological origin, in a cyclical model that imitates nature and connects with it. It implies a new way of making products from their very origin, design and allows doing business in response to the economic growth of society, environmental sustainability and the reduction of risks due to the uncertainty of prices of raw materials and energy resources" (p. fifteen). Currently the approach of the circular economy model is implemented by several countries and companies, to

García, G. A. R., \& Rivas, Y. C. (2022). The circular economy and environmental training as care of the common house. International Journal of Life Sciences, 6(1), 1-9. https://doi.org/10.53730/ijls.v6n1.3148 
transform the paradigm of the system into concrete actions and be able to achieve efficiency in recycling, reuse and valuation of waste, motivation, knowledge, and capacity are needed to innovate.

Chile is the first country in Latin America to join the Global Network of Pact for Plastics, understanding that the economic and social model of produce-consume-throw away has reached its limit. The world, Creation, is overdrawn in the use of natural resources, and pollution by waste, especially plastics, has generated and continues to generate damage that can never be repaired in the ecosystem. That is why Chile has made the decision to move towards a Circular Economy of Plastic, maintaining its value over time and extending the useful life of plastic. Therefore, the circular economy is committed to reusing materials when their useful life is exhausted, carrying out this process of recovery and recycling in the most respectful and kind way with the Creation of the environment of humanity.
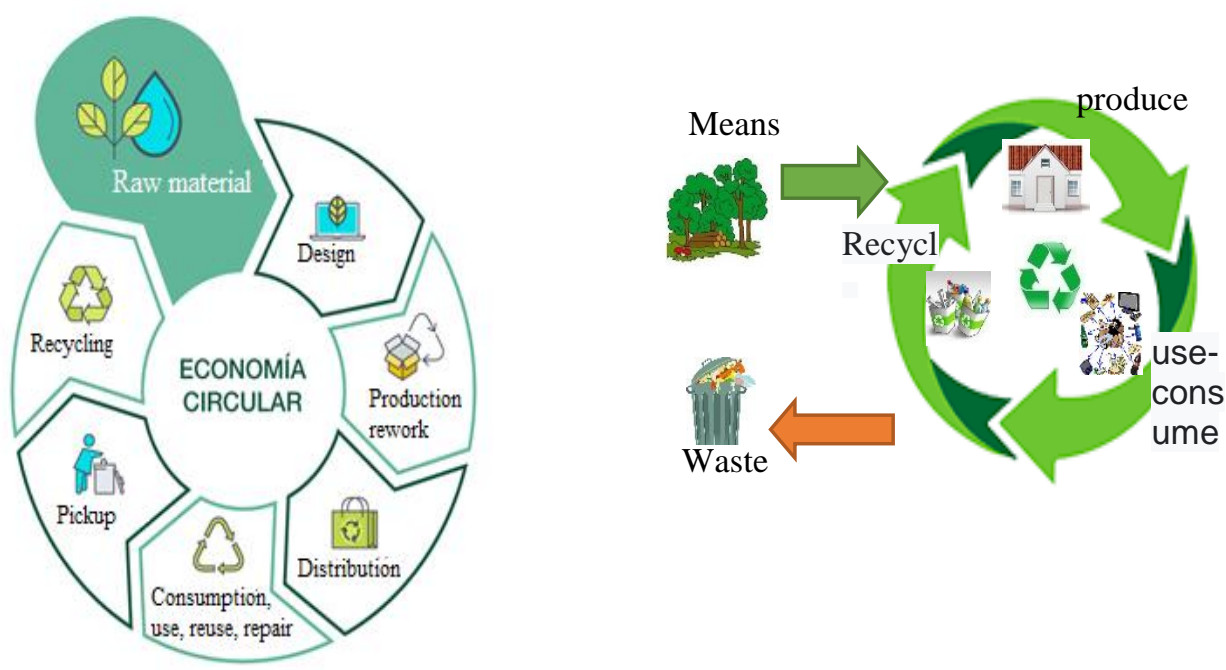

Figure 2. Circular economy

Successful circular initiative will reduce dependence on natural resources, creating value for companies and stakeholders. To implement this circular economic model, we must know its types of business in which it can be present (Morocho, 2018). Extract: the term "extract" refers to the way in which industries take resources from the environment, therefore, companies should try to make a more efficient and responsible use of the biological and technical resources, this means that the company can select the suppliers and the materials that they are going to use, based on environmental criteria that reduce their impact on nature (Dincer, 2000; Robinson, 2004).

a) Transform: once the resources are obtained, the development of the best technological practices and ecological innovations must be sought so that the product and the process are carried out in the most sustainable way possible.

b) Distribute: companies must guarantee the traceability of their products and efficiently reduce the impact on the environment. This phase has to do with the way in which the product or service is delivered to the customer.

c) Use: the circular economy seeks to reduce the impact of energy associated with the use of the product or the efficiency of the product or service itself can be improved through reuse as a second-hand product.

d) Recover: waste can be recovered in two ways: as a biological resource that can be returned to the biosphere or as a resource to be reincorporated into an industrial process (Morocho, 2018). 
Principles of the circular economy

According to Martínez \& Porcelli (2018), the circular economy is based on three fundamental principles, each of them addresses various challenges in terms of resources and the system to which industrial economies have to confront.

a) Preserve and enrich natural capital. The circular economy selects and chooses technologies and processes that use renewable resources whenever possible, in addition to increasing natural capital by providing nutrient flow in the system and creating conditions for soil regeneration.

b) Optimize the performance of resources. Circulating products, materials, and components at their maximum performance in all processes, both in biological and technical flows.

c) Design to rework, renew, recycle to keep the materials, components and economy circulating, which seeks to further extend the life of the product and optimize reuse (Cerdá \& Khalilova, 2016).

d) Ensure the efficiency of the system by revealing and redesigning to exclude negative externalities. Reduce the damage caused to systems and areas that affect people, such as: housing, health, mobility, education; as well as managing and ensuring solutions to problems such as water, air, noise and climate change pollution.

According to the concept and principles that have been defined, the following can be pointed out characteristics of the circular economy.

a) Better economic results, while reducing the use of resources.

b) Address climate change and significantly reduce the environmental impacts of resource use.

c) Finding a second life for deteriorated products, that is, it proposes the reuse and repair of products that no longer satisfy the needs of consumers.

d) Take energetic use of waste that cannot be recycled to generate energy.

e) Optimize the use of resources and promote the use of biological materials.

f) It proposes to eliminate the sale of products in many cases to implement a system of rental of goods. When the product finishes its main function.

The circular economy is a viable alternative that seeks to redefine what growth is, with an emphasis on caring for the environment, generating benefits for society. In this sense, it can be noted that caring for the environment is a cross-cutting axis and meeting point. from different disciplines in a special way with education since from there change and transformation can begin as indicated (Francisco, LUDATO SÍ, care about the common home, 2015) it is very noble to assume the duty to take care of creation with small actions everyday life and it is wonderful that education is able to motivate them to form a lifestyle. Creation is a gift from God that must be cared for, a house that all human beings inhabit and that demands special attention, a time of healing where what is destroyed is built and what is lost is restored (Cogollo Diaz et al., 2019).

Different organizations and institutions worldwide have made a call to care for the environment, in this sense Pope Francis, representative of the Catholic Church calls to take care of the common home, The encyclical "Laudato si" presents us from a perspective of faith, how to live today the responsibility of caring for the Earth, the encyclical is developed in six chapters. According to Francisco (2015), the Church does not intend to define scientific questions or substitute for politics, but I invite an honest and transparent debate, so that needs, or ideologies do not affect the common good. Pope Francis invites humanity to listen, calling everyone to ecological conversion, the Pope recognizes that "there is a growing sensitivity regarding the environment and the care of nature, and a sincere and painful concern for what is happening to our planet" (Francisco, 2015). Analyze the encyclical Laudato si, as a contribution and support to a circular economy that proposes ways to face problems in an economically viable way that preserves and optimizes the use of the resources that are used at each stage (Thyagaraju, 2016; Archana et al., 2016).

a) Chapter 1: "What is happening to our house"

The encyclical has as its starting point an analysis of reality based on data generated by science. This reality challenges readers with the different challenges related to pollution, climate change, the

García, G. A. R., \& Rivas, Y. C. (2022). The circular economy and environmental training as care of the common house. International Journal of Life Sciences, 6(1), 1-9. https://doi.org/10.53730/ijls.v6n1.3148 
depletion of natural resources (water, loss of biodiversity). Natural environment and human environment degrade together (Ildefonso Camacho, 2021).

b) Chapter 2: "The Gospel of Creation"

To face the problem raised in the previous chapter, Pope Francis rereads the stories from the Bible, offers a general vision that originates in the Judeo-Christian tradition and articulates the responsibility of the human being with respect to Creation.

\begin{abstract}
"It has been said that, since the Genesis account that invites us to « dominate "the earth (cf. Gen 1,28), the savage exploitation of nature would be favored by presenting an image of the human being as dominant and destructive. This is not a correct interpretation of the Bible as understood by the Church. If it is true that Christians have sometimes misinterpreted the Scriptures, today we must strongly reject that, from the fact of being created in the image of God and the command to dominate the earth, an absolute dominion over other creatures is deduced" (Francisco, 2015).
\end{abstract}

Understanding the Pope's call will help and motivate the care of the common home and therefore, the circular economy.

c) Chapter 3: "The human root of the ecological crisis"

The analysis of reality in chapter 1 and the biblical illumination of chapter 2 lead to the study of the root causes of the crisis. After studying what technology has meant in the world and its beneficial effects, "it also tends to exercise its dominance over the economy and politics, preventing the recognition that the market by itself does not guarantee integral human development and inclusion. social ".

d) Chapter 4:" an integral ecology "

Faced with the dominant technocratic paradigm, the encyclical seeks to oppose as an alternative a paradigm of integral ecology, it is a vision that includes the human being, since the social crisis and the environmental crisis they scourge all of humanity today, and therefore they cannot be separated. "The different aspects of this integral ecology are thus being covered: natural, economic and social ecology; cultural ecology, ecology of everyday life; justice is not forgotten with future generations" (Ildefonso Camacho, 2021).

e) Chapter 5: "Some lines of orientation and action"

Francisco, in the document proposes specific lines of action articulated around dialogue. Far from pretending to present solutions, it seeks to promote dialogue, whether in the field of international, national and local politics, of relations between economics and politics, science and religion. Having as main objective the integral ecology that leads to integral human development (Ildefonso Camacho, 2021).

f) Chapter 6: "Education and Ecological Spirituality"

Pope Francis calls for personal and communal conversations that are distant themes of consumerism and invites people to adopt lifestyles animated by ecological virtues. In the same way, it draws attention to the fact that consumer movements manage to stop acquiring products that incite consumerism, this would be effective to modify the behavior of companies that in turn leads them to consider the environmental impact and production patterns. Ecological education must provide information and form habits, this must occur in all parts of society: school, family, media, political institutions, Christian communities (Ildefonso Camacho, 2021). The encyclical concludes with two prayers: one addressed to the God of all believers regardless of their belief; a second prayer addressed to the Christian God, to the God of Jesus Christ.

\title{
4 Conclusion
}

The circular economy is a viable alternative to the linear model of "extract, produce, consume, throw away". A circular economy converts goods that are apparently at the end of a useful life into resources to create other goods, minimizing waste and contributing to well-being and common home care. The researchers have tried to give an overview of the circular economy, explaining to different authors the definitions of the circular economy, the principles on which it is based, the most relevant characteristics, and the contribution of Pope Francis in his encyclical "Laudato Si". A consumer mentality and a linear production model will cause 
shortages of natural resources. Therefore, it is important that strategies that achieve sustainable development be implemented worldwide, with a focus on the circular economy and care for the "common home". Invest in technology, where the 3R methodology (reduce, reuse, recycle) could significantly improve the processes of the productive sectors. Implement laws in all countries that regulate the methods of production and treatment of waste from industries, and provide incentives to those companies that promote sustainability in order to achieve sustainable development (Gruzin et al., 2020; Lee et al., 2013).

Acknowledgments

We thank the editors of the journal for allowing us to publish our paper.

García, G. A. R., \& Rivas, Y. C. (2022). The circular economy and environmental training as care of the common house. International Journal of Life Sciences, 6(1), 1-9. https://doi.org/10.53730/ijls.v6n1.3148 


\section{References}

Archana, .-., Datta, C., \& Tiwari, P. (2016). Impact of environmental degradation on human health. International Research Journal of Management, IT and Social Sciences, 3(1), 1-6. Retrieved from https://sloap.org/journals/index.php/irjmis/article/view/341

Booth, K. M., Pinkston, M. M., \& Poston, W. S. C. (2005). Obesity and the built environment. Journal of the American Dietetic Association, 105(5), 110-117. https://doi.org/10.1016/j.jada.2005.02.045

Cerdá, E., \& Khalilova, A. (2016). Economía circular. Economía industrial, 401(3), 11-20.

Cogollo Diaz, K., Rodiriguez Cardona, L., \& Ruiz Florez, M. (2019). Strategies On Caring For The Environment, So That The Students of The María Auxiliadora College Of Barranquilla Improve Their Ecological Commitments, Through The Contributions Made By Pope Francis In His Encyclical Laudato Yes. Graduate thesis, Medellin-Colombia.

Dincer, I. (2000). Renewable energy and sustainable development: a crucial review. Renewable and sustainable energy reviews, 4(2), 157-175. https://doi.org/10.1016/S1364-0321(99)00011-8

Francisco. (2015). Encyclical Laudato si. Rome.

Gruzin, M., Mekheal, M., Ruhlman, K., Winkowski, M., \& Petko, J. (2020). Developmental expression of doublesex-related transcripts in the common house spider, Parasteatoda tepidariorum. Gene Expression Patterns, 35, 119101. https://doi.org/10.1016/j.gep.2020.119101

Ildefonso Camacho, SJ (2021). Development: ethical and Christian perspective. Social Development Magazine , 439-473.

Jabbour, C. J. C. (2013). Environmental training in organisations: From a literature review to a framework for future research. Resources, Conservation Recycling, 74, and 144-155. https://doi.org/10.1016/j.resconrec.2012.12.017

Lee, J., Lapira, E., Bagheri, B., \& Kao, H. A. (2013). Recent advances and trends in predictive manufacturing systems in big data environment. Manufacturing letters, 1(1), 38-41. https://doi.org/10.1016/j.mfglet.2013.09.005

Lett, L. A. (2014). Global threats, waste recycling and the circular economy concept. Revista Argentina de microbiologia, 46(1), 1-2.

Martinez, A. N., \& Porcelli, A. M. (2018). Study on the Circular Economy as a Sustainable Alternative to the Decline of the Traditional Economy (First Part). LEX, 301.

Moraga, G., Huysveld, S., Mathieux, F., Blengini, G. A., Alaerts, L., Van Acker, K., ... \& Dewulf, J. (2019). Circular economy indicators: What do they measure? Resources, Conservation and Recycling, 146, 452-461. https://doi.org/10.1016/j.resconrec.2019.03.045

Morocho, F. R. A. (2018). La economía circular como factor de desarrollo sustentable del sector productivo. INNOVA Research Journal, 3(12), 78-98.

Neitz, M., \& Neitz, J. (2001). The uncommon retina of the common house mouse. Trends in neurosciences, 24(5), 248-249. https://doi.org/10.1016/S0166-2236(00)01773-2

Perron, G. M., Côté, R. P., \& Duffy, J. F. (2006). Improving environmental awareness training in business. Journal of Cleaner Production, 14(6-7), 551-562. https://doi.org/10.1016/j.jclepro.2005.07.006

Prieto-Sandoval, V., Jaca, C., \& Ormazabal, M. (2018). Towards a consensus on the circular economy. Journal of cleaner production, 179, 605-615. https://doi.org/10.1016/j.jclepro.2017.12.224

Robinson, J. (2004). Squaring the circle? Some thoughts on the idea of sustainable development. Ecological economics, 48(4), 369-384. https://doi.org/10.1016/j.ecolecon.2003.10.017

Suazo Paez, B. (2017). Circular Economy in Chile: Scope, problems and challenges in the management of the REP law.

Thyagaraju, N. (2016). Water pollution and its impact on environment of society. International Research Journal of Management, IT and Social Sciences, 3(5), 1-7. Retrieved from https://sloap.org/journals/index.php/irjmis/article/view/360 


\section{Biography of Authors}

\begin{tabular}{|l||}
\hline Gabriela Andreina Rebanales García \\
Degree in Education mention Matematíca at the Universidad Experimental Simón \\
Rodriguez-Venezuela, Specialist in Citizen Values, Universidad Catolica Andres \\
Bello. Caracas - Vnezuela. Master in Religious Sciences in Pastoral Management \\
and Leadership, Catholic University of Temuco and Salesian University Cardinal \\
Silva Henriquz. Santiago de Chile. Currently international delegate of the Catholic \\
University Andres Bello. Caracas- Venezuela and Full-time Teacher of the College \\
Alberto Pérez (Perteneciente a la red de coegios de la institución Teresiana. IT) \\
Santiago de Chile \\
Email: andreina.rebanales@gmail.com
\end{tabular}

García, G. A. R., \& Rivas, Y. C. (2022). The circular economy and environmental training as care of the common house. International Journal of Life Sciences, 6(1), 1-9. https://doi.org/10.53730/ijls.v6n1.3148 